Bangladesh J. Bot. 42(1): 45-49, 2013 (June)

\title{
EFFECT OF EPHEDRA ALATA DECNE. ON LIPIDS METABOLISM OF ASPERGILLUS FLAVUS LINK
}

\author{
AA Al-Qarawi*, EF Abd_Allah and Hashem Abeer ${ }^{1}$ \\ Plant Production Department, Faculty of Food Science and Agriculture, \\ King Saud University, P. O. Box. 2460 Riyadh 11451, Saudi Arabia
}

Key words: Aspergillus flavus, Ephedra alata, Lipids, Metabolism

\begin{abstract}
In Aspergillus flavus Link, the total lipid, sterols, neutral lipids, phospholipids and fatty acid content decreased significantly with the application of different concentrations of Ephedra alata Decne- extrtact. Gas chromatographic analysis revealed the presence of 12 fatty acids namely, (caprylic $\left(\mathrm{C}_{8}\right)$, capric $\left(\mathrm{C}_{10}\right)$, lauric $\left(C_{12}\right)$, myristic $\left(C_{14}\right)$, palmitic $\left(C_{16}\right)$, palmitoleic $\left(C_{16: 1}\right)$, stearic $\left(C_{18}\right)$, oleic $\left(C_{18: 1}\right)$, linoleic $\left(C_{18: 2}\right)$, $\alpha$ linolenic $\left(\mathrm{C}_{18: 3}\right)$, arachidic $\left(\mathrm{C}_{20}\right)$ and arachidonic $\left(\mathrm{C}_{20: 4}\right)$ with total un-saturation per cent 69.78 in the cellular lipids of A. flavus. The use of E. alata extracts induced significant alteration in fatty acid profile towards increment saturation.
\end{abstract}

\section{Introduction}

Aspergillus flavus Link is widely distributed in soil, seeds, animal fodder, human food, and agricultural commodities (Alqarawi and Abd_Allah 2010). Aflatoxins are mutagenic and hepatocarcinogenic secondary metabolites produced by some fungi including A. flavus (Alqarawi and Abd_Allah 2010). Helal et al. (2007) reported the effects of Cymbopogon citratus L. essential oil on the growth, morphogenesis and aflatoxin production of A. flavus. Alqarawi et al. (2011) reported the production of aflatoxins by $A$. flavus on both maize grains and soybean seeds.

Safe and natural food, without chemicals is a demand by the modern society. In recent years, investigations were focused on developing alternative non-chemical strategies against aflatoxigenic seedbrone A. flavus (Alqarawi and Abd_Allah 2010, Alqarawi et al. 2011). Nonchemical approach to resisting Aflavotoxin of A. flavus has been done via several means using Ephedra plant (Reichling et al. 2009, Alqarawi et al. 2011). Our previous investigation reported the antifungal potential of $E$. alata against growth parameters and aflatoxins production of $A$. flavus in vitro and in vivo has also been investigated (Alqarawi et al. 2011). Antifungal resistance system in A. flavus has been expressed as number of defense-related mechanisms (Helal et al. 2007, Alqarawi et al. 2011). Lipids metabolism has been used as sensitive monitor for mold-plant interaction (Abd_Allah et al. 2006, Van der Meer-Janssen et al. 2010). However limited information is available regarding the compliance of cellular lipids in A. flavus facing natural antifungal compounds of plant origin.

The objective of the present research was to have better understanding of lipids metabolism in A. flavus as sensitive monitor for the antifungal mechanism of E. alata.

\section{Materials and Methods}

The plant samples (E. alata) were collected from King Khalid Centre (KKC) of Wildlife Research and Development at Thumama, Riyadh, SA, in 2010. The samples were air dried, powdered and extracted with aqueous ethanol $(10: 90, \mathrm{v} / \mathrm{v})$ at $30^{\circ} \mathrm{C}$ for overnight and filtered through double layers of Whatman No. 1 filter paper after Alqarawi et al. (2011).

*Autor for correspondence: <alqarawi@ksu.edu.sa>. ${ }^{1}$ Botany and Microbiology Department, Faculty of Science, King Saud University, 2460 Riyadh 11451, Saudi Arabia. 
Aspergillus flavus isolated from seed were used for the present experiment (Alqarawi et al. 2011). The growth of $A$. flavus was carried out at static state $\left(28^{\circ} \mathrm{C} \pm 1\right)$ for 10 days using glucoseammonium nitrate salt broth medium (Brain et al. 1961) the culture was supplemented with different concentrations $(0.5,1.0$ and $2.0 \%, \mathrm{w} / \mathrm{v})$ of range plant E. alata extracts (Alqarawi et al. 2011). Control flasks were used as references. At the end of incubation period, the culture broths were filtered through pre-weighted filter paper (Whatman No.1). The filter papers with mycelial growth washed carefully with distilled water followed by drying at $80^{\circ} \mathrm{C}$ up to two successive weights were obtained. The net dry weight of mycelial growth determined and expressed as per cent of control flasks.

Lipid contents were extracted from the mycelia of A. flavus as described by Fölsh et al. (1957). Total lipids, neutral lipids and phospholipids were estimated according to Marsh and Weinstein (1966), Amenta (1964) and Rouser et al. (1970), respectively. Methanolysis was done according to Kates (1972) and methyl esters were analyzed according to Johnson and Stocks (1971). Standard fatty acids samples were used as reference. The statistical analysis was carried out according to Daniel (1987).

\section{Results and Discussion}

The extracts of E. alata at concentrations of $0.5,1.0$ and $2.0(\mathrm{w} / \mathrm{v})$ were effective against $A$. flavus. Significant decrease in mycelial growth by per cent of 33.5, 56.9 and 79.8, respectively compared with control was observed (Fig 1). Species belonging to Ephedra possess variable antifungal potential against many pathogen plants as well as seedbrone aflatoxigenic molds such

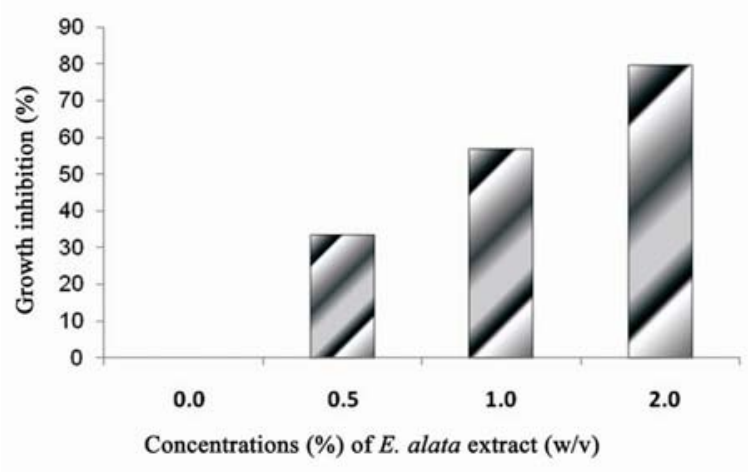

Fig. 1. Effect of different concentrations (Control, 0.5, 1.0, 2.0\%) of E. alata extract (w/v) on growth inhibition (\%) of A. flavus.

Table 1. Effect of different concentrations of E. alata extracts (w/v) on total lipid, total sterols, total neutral lipid and total phospholipid contents (mg/g dry weight) of A. flavus.

\begin{tabular}{lcccc}
\hline \multirow{2}{*}{ Treatments } & \multicolumn{4}{c}{ Lipids fractions contents (mg/g dry weight) of A. flavus } \\
\cline { 2 - 5 } & TL & TS & TN & TP \\
\hline Control & 6.44 & 3.27 & 22.84 & 12.62 \\
$0.5 \%(w / v)$ & 5.05 & 3.07 & 17.12 & 10.17 \\
$1.0 \%(w / v)$ & 3.71 & 2.73 & 13.06 & 6.58 \\
$2.0 \%(w / v)$ & 1.84 & 2.16 & 8.04 & 4.46 \\
\hline LSD at: 0.5 & 0.61 & 0.52 & 2.45 & 1.00 \\
\hline
\end{tabular}

$\mathrm{TL}=$ total lipid, $\mathrm{TS}=$ total sterol, $\mathrm{TN}=$ total neutral lipid, $\mathrm{TP}=$ total phospholipids. 


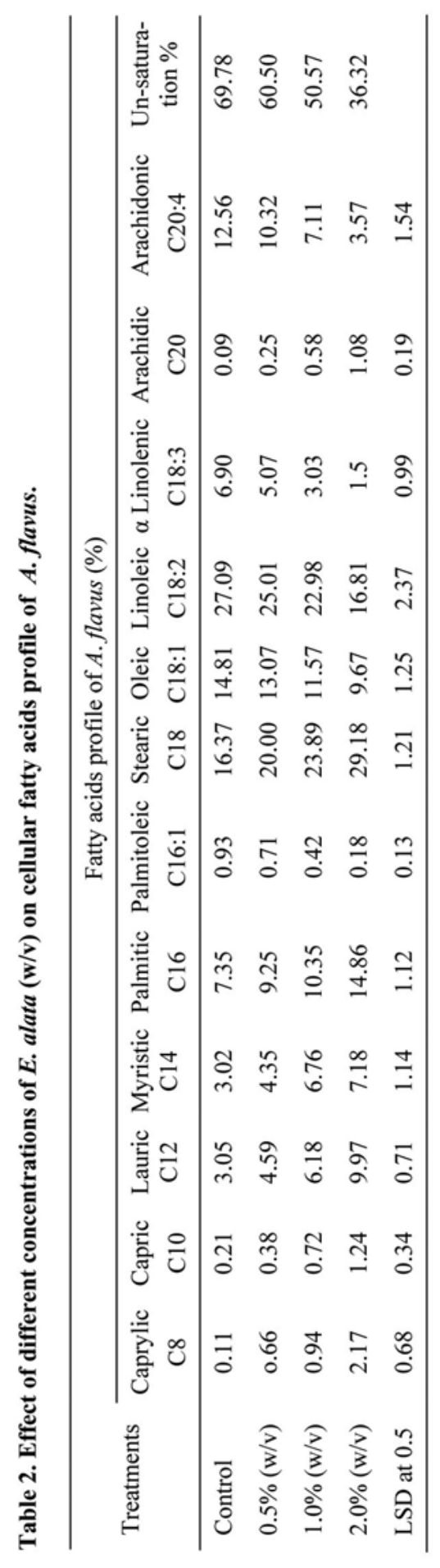


as Aspergillus parasiticus (Bagheri et al. 2009) and Aspergillus flavus (Alqarawi et al. 2011). Also, recent investigation revealed the antimicrobial potential of Ephedra against pathogenic bacteria (Cottiglia et al. 2005). The antifungal activity of $E$. alata has been attributed because of the presence of cis-3,4-methanoproline (Caveney et al. 2001), citronellol (Rosato et al. 2007) and heptadecane (Bagheri et al. 2009).

The E. alata extracts of caused significant decrease in contents of total lipids, total sterols, total neutral lipids and phospholipids of A. flavus as compared with those of control (Table 1). It has been established that lipid moieties are an important materials in biological membranes playing an essential role in their permeability (Georgopapadakou and Walsh 1996). Similar alteration has been recognized in Trichoderma koningii (El-Mougith 1999) stressed by different chemical fungicides. It was also reported that the incorporation of fungal lipid moieties strongly inhibited in response to antifungal compounds from plant origin (Helal et al. 2007) which caused an alterations in fungal cell membrane function and leakage of ions (Reichling et al. 2009).

Gas chromatographic analysis of cellular fatty acids (methyl ester) of $A$. flavus revealed the presence of 12 fatty acids, namely caprylic $\left(\mathrm{C}_{8}\right)$, capric $\left(\mathrm{C}_{10}\right)$, lauric $\left(\mathrm{C}_{12}\right)$, myristic $\left(\mathrm{C}_{14}\right)$, palmitic $\left(\mathrm{C}_{16}\right)$, palmitoleic $\left(\mathrm{C}_{16: 1}\right)$, stearic $\left(\mathrm{C}_{18}\right)$, oleic $\left(\mathrm{C}_{18: 1}\right)$, linoleic $\left(\mathrm{C}_{18: 2}\right)$, a linolenic $\left(\mathrm{C}_{18: 3}\right)$, arachidic $\left(\mathrm{C}_{20}\right)$ and arachidonic $\left(\mathrm{C}_{20: 4}\right)$ (Table 2$)$. The saturated fatty acids were caprylic $\left(\mathrm{C}_{8}\right)$, capric $\left(\mathrm{C}_{10}\right)$, lauric $\left(\mathrm{C}_{12}\right)$, myristic $\left(\mathrm{C}_{14}\right)$, palmitic $\left(\mathrm{C}_{16}\right)$, stearic $\left(\mathrm{C}_{18}\right)$, arachidic $\left(\mathrm{C}_{20}\right)$ and un-saturated fatty acids were palmitoleic $\left(\mathrm{C}_{16: 1}\right)$, Linoleic $\left(\mathrm{C}_{18: 2}\right), \alpha$ Linolenic $\left(\mathrm{C}_{18: 3}\right)$, arachidonic $\left(\mathrm{C}_{20: 4}\right)$. Present results corroborate those of Wilson et al. (2004), Helal et al. (2007) and Zain (2009) who reported that oleic $\left(\mathrm{C}_{18: 1}\right)$ and linoleic $\left(\mathrm{C}_{18: 2}\right)$ acids were the most common unsaturated fatty acids in cellular lipids of Aspergillus. The present investigation provides that the different concentrations of E. alata extract caused significant decrease in total un-saturated fatty acids $\left(\mathrm{C}_{16: 1}, \mathrm{C}_{18: 1}, \mathrm{C}_{18: 2}, \mathrm{C}_{18: 3}\right.$ and $\mathrm{C}_{20: 4)}$. The percent of inhibition of total un-saturated fatty acids was 13.3, 27.5 and 47.9 , as compared with control (Table 2). Per cent of un-saturated fungal fatty acids has been reported as an important biochemical and physiological monitor for fungal development and adaptation (Wilson et al. 2004). The alteration in fatty acids composition has been related to mold resistance against the reverse biotic stress (Helal et al. 2007) to maintain the membrane fluidity of living cell (Davidse 1973). A decrease in membrane viscosity was antagonized by synthesis of saturated fatty acids (Rosas et al. 1980).

\section{Acknowledgment}

This research project was financially supported by King Saud University, Deanship of Scientific Research, College of Food and Agricultural Sciences Research Center.

\section{References}

Abd_Allah EF, Abeer Hashem and SM Ezzat 2006. Lipid metabolism in tomato and bean as a sensitive monitor for biocontrol of wilt diseases. Phytoparasitica 34: 516-522.

Alqarawi AA and EF Abd_Allah 2010. Maintenance of Ephedra alata seed viability via storage containers. Amer. J. Plant Sci. 1: 138-146.

Alqarawi AA, EF Abd_Allah and Hashem Abeer 2011. Ephedra alata as biologically-based strategy inhibit aflatoxigenic seed borne mold. African J. Microbiol. Res. 5: 2297-2303.

Amenta JS 1964. A rapid method for quanti_cation of lipids separated by thin layer chromatography. J. Lipid Res. 5: 270-272.

Bagheri G, M Bigdeli, GM Shams and AM Razzaghi 2009. Inhibitory effects of Ephedra major host on Aspergillus parasiticus growth and aflatoxin production. Mycopathologia 168: 249-255. 
Brain PW, AW Dowkins, JF Grove, DL Hemming and GLF Norris 1961. Phytotoxic compounds produced by Fusarium equiseti. J. Bot. 12: 1-12.

Caveney S, DA Charlet, H Freitag, M Maier-Stolte and A Starratt 2001. New observations on the secondary chemistry of world Ephedra (Ephedraceae). Ame. J. Bot. 88: 1199-1208.

Cottiglia F, L Bonsignore, L Casu and D Deidda 2005. Phenolic constituents from Ephedra nebrodensis. Natl. Prod. Res. 19: 117-123.

Daniel WW 1987. Biostatistics: A foundation for Analysis in the Health Science. 4th ed., John Wiley and Sons, New York, NY. pp. 292-293.

Davidse LC 1973. Antimitotic activity of methyl benzimidazol-2yl carbamate (MBC) in Aspergillus nidulans. Pesticide Biochem. Physiol. 3: 317-325.

El-Mougith AA 1999. Effect of benomyl on the growth and lipid composition of Trichoderma koningii. Folia Microbiol. 44: 41-44.

Fölsh J, M Lees and GH Sloane-Stanley 1957. A simple method for the isolation and puri cation of total lipids from animal tissues. J. Biol. Chem. 226: 497-509.

Georgopapadakou NH and TJ Walsh 1996. Antifungal agents: chemotherapeutic targets and immunologic strategies. Antimicrob. Agents Chemother. 40: 279-291.

Helal GA, MM Sarhan, ANK Abu Shahla, EK Abou El-Khair 2007. Effects of Cymbopogon citratus L. essential oil on the growth, morphogenesis and aflatoxin production of Aspergillus flavus ML2- strain. J. Basic Microbiol. 47: 5-15.

Johnson A and R Stocks 1971. Gas-liquid chromatography of lipids. In: A Johnson and J Davenport (eds.) Biochemistry and Methodology of Lipids. Wiley Interscience, New York, NY.

Kates M 1972. Techniques of lipidology. In: TW Work and E Work (eds.) Laboratory Techniques in Biochemistry and Molecular Biology. North-Holland Publishing Co., Amsterdam, the Netherlands.

Marsh JB and DB Weinstein 1966. Simple charring method for determination of lipids. J. Lipid Res. 7: 574576.

Reichling J, P Schnitzler, U Suschke and R Saller 2009. Essential oils of aromatic plants with antibacterial, antifungal, antiviral, and cytotoxic properties-an overview. Forsch Komplementmed 16: 79-90.

Rosas SB, M Secco and NE Ghittoni 1980. Effects of pesticides on the fatty cid and phospholipid composition of Escherichia coli. Appl. Environ. Microbiol. 40: 231-234.

Rosato A, C Vitali and N De Laurentis 2007. Antibacterial effect of some essential oils administered alone or in combination with Norfloxacin. Phytomedicine 14: 727-32.

Rouser G, S Fleischer and A Yamamoto 1970. Two dimensional thin layer chromatographic separation of polar lipids and determination of phospholipids and phosphorus analysis of spots. Lipids 5: 494-496.

Van der Meer-Janssen YPM, J van Galen, JJ Batenburg and JB Helms 2010. Lipids in host-pathogen interactions: Pathogens exploit the complexity of the host cell lipidome. Prog. Lipid Res. 49: 1-26.

Wilson RA, AM Calvo, P Chang and P Keller Nancy 2004. Characterization of the Aspergillus parasiticus $\Delta$ ${ }^{12}$-desaturase gene: a role for lipid metabolism in the Aspergillus-seed interaction. Microbiology 150: 2881-2888.

Zain ME 2009. Effect of olive oil on secondary metabolite and fatty acid profiles of Penicillium expansum, Aspergillus flavus, A. parasiticus and A. ochraceus. Australian J. Basic Appl. Sci. 3: 4274-4280.

(Manuscript received on 26 November, 2011; revised on 15 September, 2012) 